\title{
Gallbladder cancer in Chile and selected countries
}

\author{
Iván Serra', V. García ${ }^{2}$, M. Yamamoto ${ }^{3}$ and G. Cavada'
}

\section{RESUMEN}

Se presenta un trabajo descriptivo que analiza la mortalidad por cáncer vesicular en países seleccionados por presentar una gran magnitud y tendencia al aumento como Chile, Japón y Suecia. Se ha considerado además a otros países como Estados Unidos y algunos escandinavos para apreciar contrastes. El período de estudio comprende desde 1953 hasta 1987 y los datos provienen de publicaciones existentes, particularmente un estudio efectuado en Japón en 1992 con respaldo de la Organización Mundial de la Salud. Las tasas están separadas por sexo y ajustadas a la población mundial para una adecuada comparabilidad.

Se observa que Estados Unidos, al igual que la mayoría de los países desarrollados, tiene tasas de mortalidad por cáncer vesicular bajas, además de decrecientes en las cuatro décadas estudiadas. Es llamativo que su población blanca tiene tasas más elevadas en forma inicial, particularmente en mujeres, pero la tendencia al descenso se presenta en los dos grupos raciales (más marcadamente en población blanca) y en ambos sexos. Esta evolución conduce a un acercamiento de las magnitudes para estos cuatro grupos poblacionales en la década del 80.

En los países escandinavos, Suecia tiene las tasas más elevadas, seguido por Finlandia, pero las magnitudes para este último son inferiores en la década del 80 además de tender a una estabilización tanto en hombres como en mujeres.

Se aprecia que las tasas para hombres en Suecia y Japón (Aoki et al. 1992) ascienden desde 1,4 y 1,5 por 100.000 en el quinquenio $1958-62$ hasta 2,5 y 5,3 por 100.000 respectivamente, en el quinquenio 198387, mientras que en Chile se elevan desde un mismo

1 School of Public Health, Faculty of Medicine, University of Chile.

2 Center for Human Nutrition, Faculty of Medicine, University of Chile.

3 Department of Hygiene \& Preventive Medicine, University of Niigata. valor inicial de 1,3 hasta alcanzar 5,8 por 100.000 en 1983-87, una magnitud bastante más alta que en Suecia pero poco superior a la de Japón.

Las tasas para mujeres en Suecia y Japón ascienden desde 2,5 y 1,5 por 100.000 en 1958 8-62 (según Aoki et al. ob.cit.) a 4,3 y 5,3 por 100.000 respectivamente, en 1983-87. En Chile, las magnitudes son muy superiores y además ascendentes desde 6,2 en 1968-72 hasta alcanzar 13,1 por 100.000 en 1983-87, condición que ratifica una situación de preeminencia mundial marcada que había sido descrita.

Se plantea la hipótesis de que la evolución señalada para la mortalidad por cáncer vesicular en diferentes países puede estar correlacionada con sus tasas de colecistectomía, hipótesis que ha sido postulada por diversos autores. Será necesario efectuar estudios actualizados, en particular para Suecia y Japón que no han publicado datos recientes o no los tienen disponibles, para ratificar o rechazar esta hipótesis.

\section{Introduction}

Gallbladder and biliary tract cancers, considered as a unique clinical entity during decades including the 9th International Classification of Diseases (19851995), are relatively unfrequent in most countries. Additionally, an international trend of decreasing rates of incidence mortality is observed in the last decades, particularly in developed countries, with a few exceptions such as Sweden and Japan. (Aoki et al., 1992). In consequence, world statistics for cancer do not include cancer nor main bile duct cancers (Muir et al., 1987, Parkin et al., 1992, 1993, 1997).

To have separate figures for the cancers originated in the gallbladder (Code 156.1- 9th 1CD), in contrast with those originated in the choledocus (Code 156.2) and Vater's ampulla (Code 156.3) is rare in world literature and it depends on registries or special studies. Sweden (Malken et al., 1986) and Chile (Serra et al., 1990) are examples with information on this matter among countries with a high incidence and mortality presenting about $70 \%$ 
and $90 \%$ of gallbladder origin respectively and not about $50 \%$, the common epidemiological situation in developed nations (Serra et al., 1997). It is an important issue because gallbladder cancer is closely related to gallstone disease (Hart et al., 1971) while main bile duct cancers are more similar to pancreatic cancer with no evidence of relationship with gallstones (Fraumeni, 1975). The objetive of this study is to present the evolution of biliary tract cancer in different countries with emphasis in Chile, Japan and Sweden.

\section{Material and Method}

It is a descriptive study based on published data. The information has been directed to countries with different incidence rates but focused on Chile, Japan and Sweden for having a high incidence and mortality, jointly with an increase of both rates that can be considered in practice as equivalent, given the high case mortality and short survival of these cancers, particularly gallbladder cancer. Data from some countries showing changes in incidence and morta- lity have been included only to provide a larger scope on the epidemiological situation of gallbladder cancer in the world during the last decades.

Main interpretation of the changes in gallbladder cancer incidence, either increase or decrease, has been already provided in the literature and data corresponding to cholecystectomy rates in the countries analysed are not included in this study.

Chilean information is usually not available in the world literature in spite of the well known condition of being the country with the highest incidence and mortality from gallbladder cancer. This paper means an effort to include Chile with adjusted rates to the world population in the same period of time to establish a valid international comparison. The figures corresponding to Chile are estimates, both for men and women.

They were produced through a linear regression based on published information for Japan and Sweden. Trend for Chile used four years for every year considered: 1970 (1968-72), 1975 (1973-77), 1980 (1978-82) and 1985 (1983-87). It was calculated the

Fig. : TRENDS OF GALLBLADDER CANCER MORTALITY IN THE UNITED STATES.

WOMEN AND MEN 1958-1987

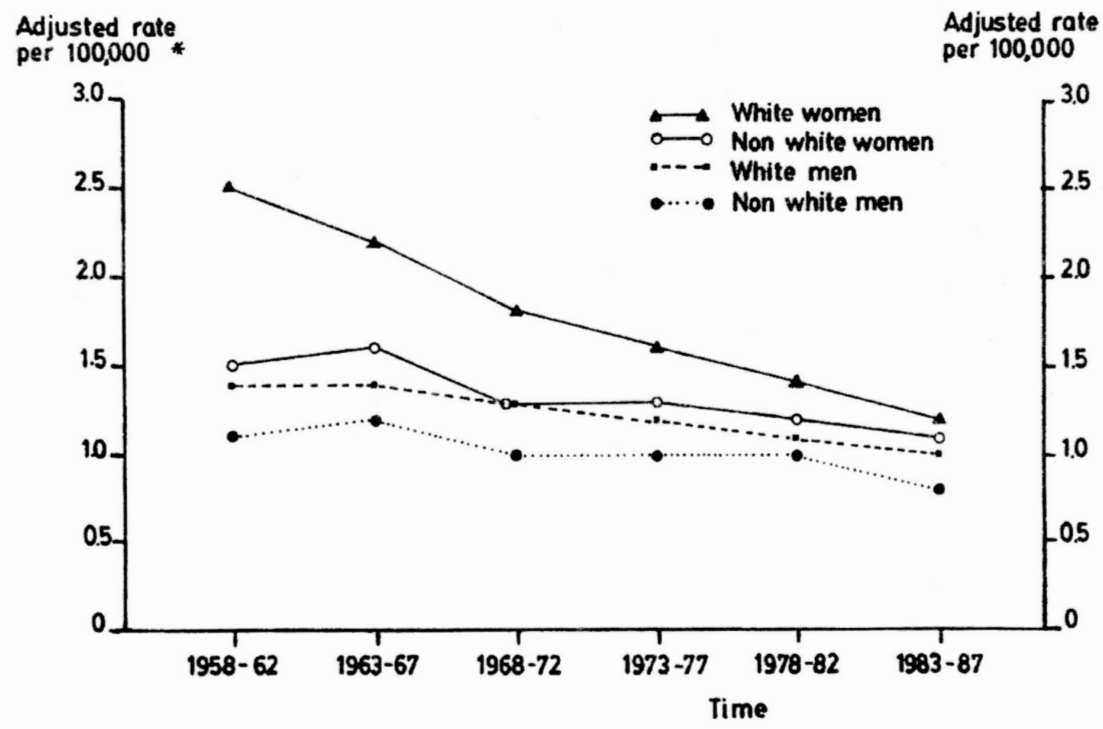

* To world population

Fig. 1. Trends of gallbladder cancer mortality in the United States. 
Fig. 2

\section{TRENDS IN GALLBLADDER CANCER MORTALITY IN SCANDINAVIAN COUNTRIES.}

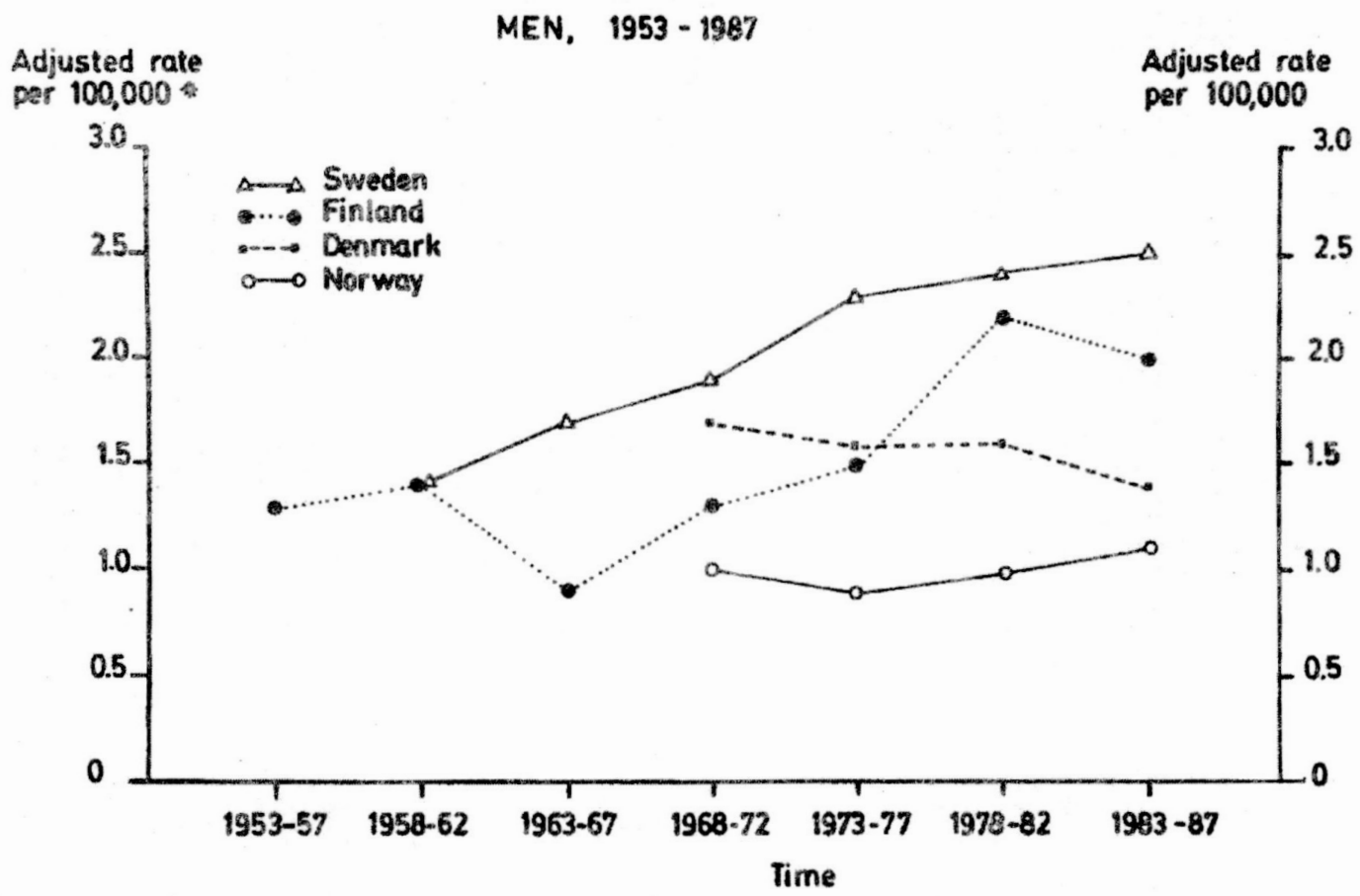

* in world posulation

Fig. 2. Trends of gallbladder cancer mortality in Scandinavian countries.

coefficient of variation and the statistical significance of the changes observed.

\section{Results}

Gallbladder cancer mortality reflecting the situation in the United States corresponds to both origins: gallbladder and main bile duct showing, a marked decrease and an approaching trend of adjusted rates, both for men and women and both for white and non white people, between 1958 and 1987. All the levels, even at the beginning of the period, are relatively low (Fig. 1).

The comparison among Scandinavian countries, which are traditionally considered countries with a high level of incidence, shows that Sweden and Finland share a clear trend to an increase in the same period of time, more relevant for Sweden and for the 50's and 60's compared with the 70's and 80's. Denmark and Norway, initially in a similar level of incidence or mortality compared with Sweden and Finland, show a great stability with the result of a relative lower level at the end of the 80 's. The trends described are observed both for men and women
(Figs. 2 and 3).

Several facts may be established when Chile, Japan and Sweden are compared, three countries that show a high level and larger increase of gallbladder cancer incidence and mortality in the world, including all biliary cancers. One of them is the order of both the level and the increase that is the one already described, with the highest level and increase in Chile. Adjustment of rates does not change the order but it atenuates the diferences (data not shown).

The changes observed are different whether men or women are considered.

In the case of men, Japan shows a rather similar and marked increase compared with Chile (in the highest level) and Sweden in the early 70's but Sweden in the late 70's and particularly in the 80's, shows a certain stability in its increase. Increases in Japan and Chile are significant, with a $p=.0043$ and .0046 respectively. Differences in the increase between Chile and Japan are not significant but between Chile-Japan and Sweden are significant (Fig. 4).

The evolution in women is somewhat different. 
Fig. 3

TRENDS IN GALLBLADDER CANCER MORTALITY IN SCANDINAVIAN COUNTRIES

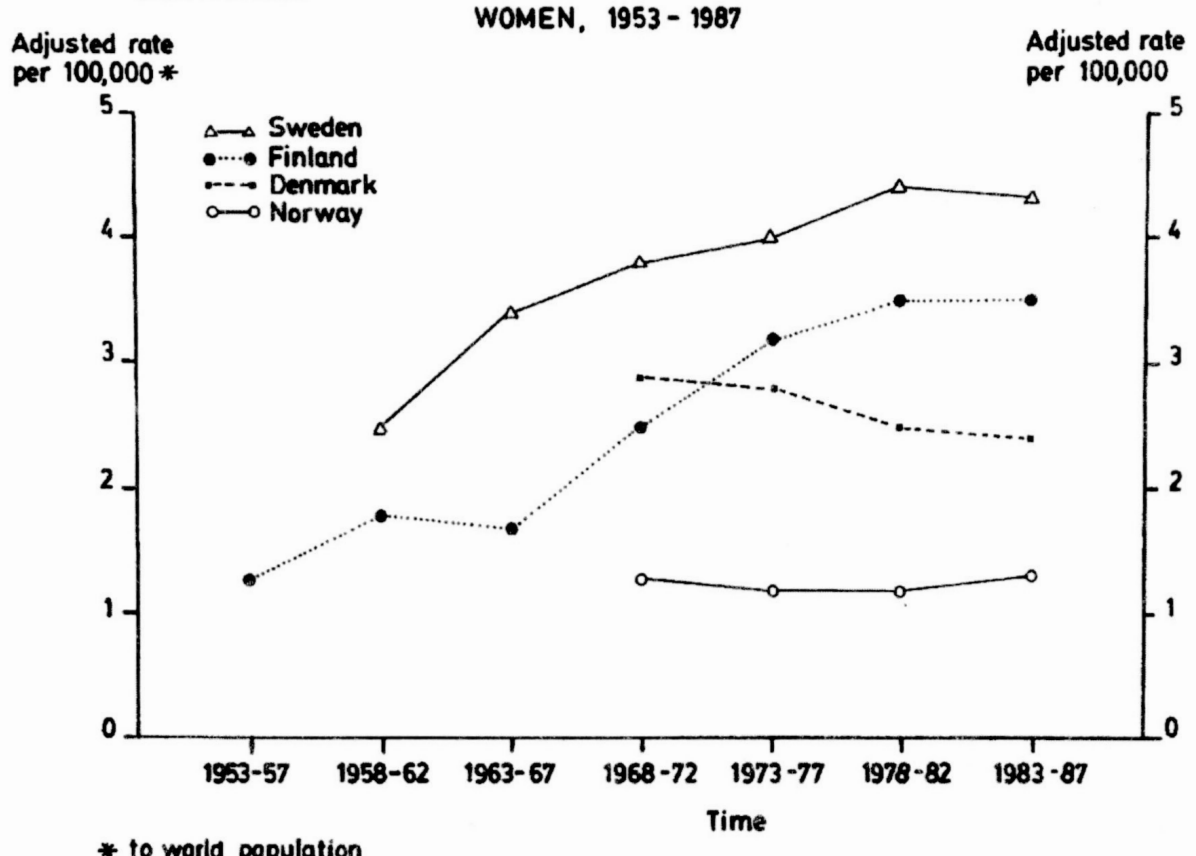

Fig. 3. Trends of gallbladder cancer mortality in Scandinavian countries.

Sweden has a trend to a lesser increase, Chile and Japan show a strong increase besides a very high mortality in the early 70's for the three countries, trend that is even more marked in the late 70's and in the 80 's just for Chile and Japan. Increases observed for these two countries are statistically very significant ( $\mathrm{p}=.0076$ and .0006 respectively). Rates for Japan would have decreased in the 90's while Chile keeps its trend to an increase both for men and women (data not shown). Information for Sweden in the current decade has not been available (Fig.5).

\section{Discussion}

Gallbladder cancer has been always frequent in Chile but its incidence rate measured through mortality began to increase since early 1970 's, reaching the highest historical figure in 1997 with 1,711 deaths and a crude mortality rate of 11.7 per 100,000 . The rate for men was 6.2 and for women 17.5 per 100,000 in the same year.

The main risk factor for gallbladder cancer is gallstones, a disease very prevalent in Chile according to a classical study (Puffer and Griffith,
1967) and more recent investigations (Medina, 1988, Miguel et al., 1998). Prevalence of gallstones is estimated in $28.5 \%$ of the total adult population (18 years and more), according to studies in living people (Miguel et al., 1998). It is assumed that it could have been the same during the last decades. Both gallstone disease and gallbladder cancer tend to show higher frequencies in Andean or Pacific countries in South or Central America such as Mexico, Bolivia or Chile compared with Atlantic and Caribean countries such as Cuba, Brasil or Argentina (figures not provided).

Gallstone disease is also very prevalent in Sweden (Norrby et al., 1986; Muhrbeck and Ahlberg, 1998) but it seems to be unfrequent in Japan that would not in spite of the evidence of an increase that would not be well documented in the 90's (Nomura et al., 1988). Gallstone disease has in the United States a comparative low prevalence, particularly in black people with the exception of Hispanics (Diehl et al., 1980).

Other risk factor for gallbladder cancer and related to gallstones is cholecystectomy, rate that shows a decrease both in Chile (Serra et al., 1990) and Sweden (Broden et al., 1978, Broden and 
Fig. 4

TRENDS OF GALLBLADDER CANCER MORTALITY IN CHILE, JAPAN AND SWEDEN.

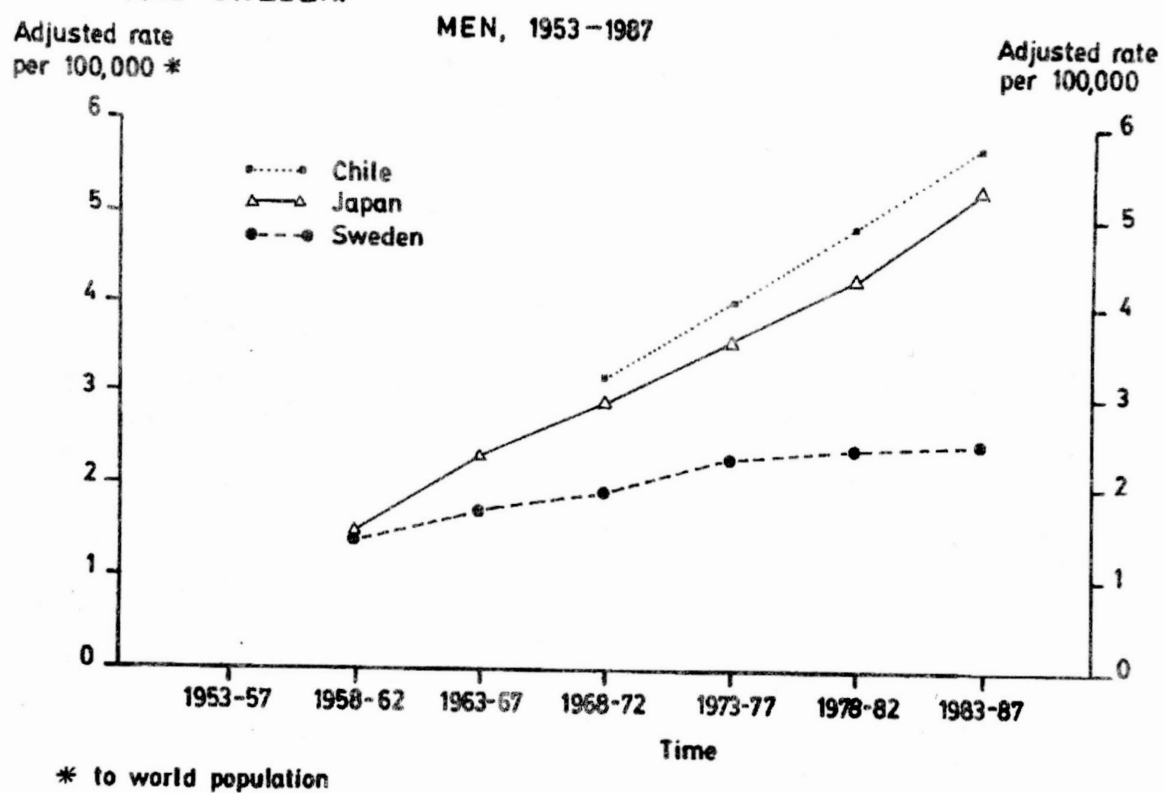

Fig. 4. Trends of gallbladder cancer mortality in Chile, Japan and Sweden.

Fig. 5

TRENDS OF GALLBLADDER CANCER MORTALITY IN CHILE, JAPAN AND SWEDEN.

Adjusted rate
per $100,000 *$

WOMEN, $1953-1987$

Adjusted rate

14

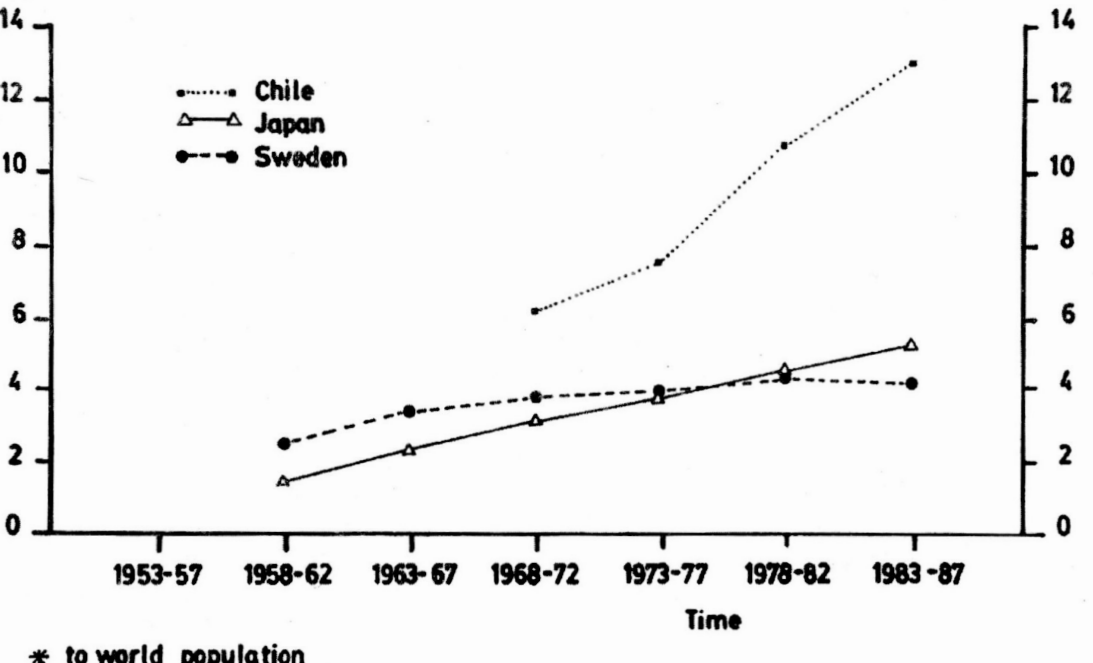

* to world population

Fig. 5. Trends of gallbladder cancer mortality in Chile, Japan and Sweden. 
bengtsson, 1980) in the last decades. It may be the best explanation for the increase observed in the evolution of gallbladder cancer mortality in these two countries so different in many aspects. In the case of Japan, the information about the level and evolution of cholecystectomy rates is not available in spite of the assumption of a recent increase given the availability of laparoscopic procedures.

A consensus has developed to explain the epidemiological change observed for this cancer in Chile during the last three decades. It is accepted that the best explanation for its huge and sharp increase is the contemporary and equivalent decrease in cholecystectomy rates in all the regions of the country (Sena, 1992). The decrease has been more marked for women, particularly young women, providing a good explanation for the increase in gallbladder cancer mortality observed that is different in men and women, being higher also in young women.

Only two other countries show an increase in incidence rates for gallbladder cancer in the 1980's which are Japan and Sweden, but the increase is moderate and in a lower level in both countries. The decrease of cholecystectomy rates is clearly associated with the observed increase for gallbladder cancer in Sweden (Broden et al., 1978; Broden and Bengtsson, 1980) but this data is missing for Japan, a relevant information because this country presents a relatively low prevalence of gallstone disease in contrast to Sweden that has a very high prevalence. The negative correlation between cholecystectomy rate and gallbladder cancer mortality was first shown in Sweden and it has been largely demonstrated in different countries (Serra et. al., 1990; Serra et al., 1991; Broden et al., 1978; Broden and Bengtsson, 1980; Serra et al., 1999; Chianale et al., 1995; Diehl and Beral, 1971). Further studies are needed to clarify international changes in the epidemiology of biliary cancers, particularly in the gallbladder site, that seems to be rather specific according to the involved populations.

\section{REFERENCES}

AOKI, K., KURIHARA, M., HAYAKAWA, N., SUZUKI, S. 1992 Death rates for Malignant Neoplasms for Selected Sites by Sex and Five. Year Group in 33 Countries 195357 to 1983-87. UICC, The Nagoya University Press, Nagoya, Japan.

BRODEN, G.,AHLBERG, J., BENGTSSON, L., HELLERS, G. 1978 The incidence of carcinoma of the gallbladder and bile ducts in Sweden 1958-1972. Acta Chir. Scand. 482 suppl: 24-25.

BRODEN, G., BENGTSSON, L. Carcinoma of the gallbladder. 1980 Its relation to cholelithiasis and to the concept of prophylactic cholecystectomy. Acta Chir. Scand. 500 suppl: 15-18.

CHIANALE, J., DEL PINO, G., NERVI, F. Increasing gallbladder 1990 cancer mortality rate during the Iast decade in Chile, a high-risk area. Int. J. Cancer 46:1131-1133.

DIEHL, A.K., STERN, M.P., OSTROWER, V.S., FRIEDMAN, 1980 P.C. Prevalence of clinical gallbladder disease in Mexican-American, Anglo, and black women. South Med. J. 73:438-443.

DIEHL, A.K., BERAL, V. Cholecystectomy and changing 1981 mortality from gallbladder cancer. Lancet 2:187-189.

FRAUMENI, J.F. Cancers of the pancreas and biliary tract: 1975 epidemiological considerations. Cancer Res. 35:3437-3446.
HART, J., MODAN, B., SHANI, M. Cholelithiasis and the 1971 aetiology of gallbladder neoplasms. Lancet: 1151-1153.

MALKEN, H.S.R, MCLAUGHLIN, J.K., MALKEN, B., et al. 1986 Biliary tract cancer and occupation in Sweden. Br. J. Ind. Med. 43:357-262.

MEDINA, E. Las enfermedades digestivas en Chile. 1988 Panorama epidemiológico. Rev. Med. Chile 116:282-288.

MIQUEL, J.F., COVARRUBIAS, C., VILLARROEL, L., 1998 MINGRONE, G., GRECO, A. V., PUGLIELLI, L. et al. Genetic Epidemiology of Cholesterol Colelithiasis Among Chilean Hispanics, Amerindians, and Maoris. Gastroenterology 115:937946.

MUHRBECK, O., AHLBERG, J. Prevalence of gallstone disease 1992 in a Swedish population. Scand J. Gastroenterol 30:1125-1128.

MUIR, C., WATERHOUSE, J., MACK, T., POWELL, J., 1987 WHELAN, S. Cancer Incidence in Five Continents, Vol V, IARC Scient Publ. $\mathrm{N}^{\circ} 88$, Lyon.

NOMURA,H.,KASHIWAGI,S.,HAYASHI,J.,KAJIYAMA,W., 1988 IKERATSU, H., NOGUCHI, A. Prevalence of gallstone disease in a general population of Okinawa, Japan. Am. J. Epidemiol 128:598-605.

NORRBY, S., FAGERBERG, G., SJODAHL, R. Decreasing 1986 incidenceofgallstonediseaseinadefined Swedish population. Scand. J. 
Gastroenterol 21:158-162.PARKIN, D.M., MUIR, C.S., WHELAN, S.L., GAO, Y.T.,

1992 FERLAY, J., POWELL, J. Cancer Incidence in Five Continents, Vol VI, IARC Scient. Publ. $N^{\circ} 120$, Lyon.

PARKIN, D.M., PISANI, P., FERLAY, J. Estimates of the 1993 world-wide incidence of eighteen major cancers in 1985. Int. J. Cancer 54: 594606

PARKIN, D.M., WHELAN, S.L., FERLAY, J., RAYMOND, L., 1997 YOUNG, J. Cancer Incidence in Five Continents, Vol VII, IARC Scient. Publ. $\mathrm{N}^{\circ} 143$, Lyon.

PUFFER, R. R., GRIFFITH, G.W. Patterns of urban mortality. 1967 Pan American Health Organization Scient. Publ. 151, pp 106-108, Washington, DC

SERRA, I., CALVO, A., MATURANA, M., SHARP A. Biliary
1990 tract cancer in Chile. Intl Cancer 46:965-971.

SERRA I., YAMAMOTO, M., GARCIA, V., DECINTI, E. Diet, 1997 gallstones and gallbladder cancer. Jpn. J. Cancer Clin. 43: 404-412.

SERRA, I., CALVO, A., MATURANA, M. Changing trends of 1990 gallbladder cancer in Chile, a highrisk area. Letter to the editor. Int. J. Cancer. 45:376-377.

SERRA, , CALVO, A., MATURANA, M., DECINTI, E. Causas 1991 del incremento del cáncer vesicular en Chile. Rev. Med. Chile 119:78-82.

SERRA, I. Gallbladder cancer, a high priority as a public health 1999 in Chile. In "Epidemiology of gallbladder and bile duct cancers". Eds. M. Yamamoto, I. Serra, K. Endoh and K. Ogoshi, Smith-Gordon Edit., London, pp. 95-97. 
